


\title{
MORPHOLOGICAL CHARACTERISTICS, PRODUCTIVITY AND QUALITY OF THREE NAPIER GRASS (Pennisetum purpureum Schum) CULTIVARS HARVESTED AT DIFFERENT AGE
}

\author{
Budiman $^{1,2}$, R. D. Soetrisno ${ }^{1}$, S. P. S. Budhi ${ }^{1}$ and A. Indrianto ${ }^{3}$ \\ ${ }^{1}$ Animal Science Faculty, University of Gadjah Mada, \\ Jl. Fauna 3 Bulaksumur 55281 Yogyakarta - Indonesia \\ ${ }^{2}$ Permanent Address: Animal Science Faculty, Hasanuddin University, \\ Tamalanrea Campus, Makassar 90245 - Indonesia \\ ${ }^{3}$ Faculty of Biology, University of Gadjah Mada, \\ Jl. Teknika Selatan, Sekip Utara Yogyakarta 55281 - Indonesia \\ Corresponding E-mail:budiman_ek58@yahoo.com
}

Received October 25, 2012; Accepted Novemver19, 2012

\begin{abstract}
ABSTRAK
Penelitian ini dilakukan untuk mengetahui karakteristik morfologi, produktivitas dan kualitas rumput gajah kultivar Taiwan, King dan Mott yang dipanen pada umur 8 dan 13 setelah tanam. Pengaruh kultivar dan umur panen disusun dalam Rancangan Tersarang (3x2). Peubah yang diamati terdiri atas karakteristik morfologi, produksi bahan kering dan kualitas hijauan. Hasil penelitian menunjukkan bahwa karakteristik morfologi, rasio daun batang, kadar serat, kandungan protein kasar dan kecernaan in vitro bahan kering rumput gajah kultivar Taiwan dan King tidak berbeda, namun keduanya memiliki karakteristik morfologi, kandungan serat lebih tinggi $(\mathrm{P}<0,05)$ dibandingkan dengan kultivar Mott, sebaliknya rasio daun batang, kandungan protein kasar dan kecernaan in vitro bahan kering kultivar Mott lebih tinggi $(\mathrm{P}<0,05)$ dibandingkan dengan kultivar Taiwan dan King. Secara umum, terjadi peningkatan tinggi tanaman dan kadar serat pada umur 13 minggu, sedangkan kandungan protein kasar dan kecernaan in vitro bahan kering menurun. Disimpulkan bahwa produksi bahan kering tertinggi terdapat pada kultivar Taiwan dan King, sedangkan kualitas tertinggi terdapat pada kultivar Mott. Produksi bahan kering tertinggi pada umur 13 minggu, sedangkan kualitas tertinggi pada umur 8 minggu setelah tanam untuk semua kultivar diuji.
\end{abstract}

Kata kunci : kualitas, kultivar, produksi, rumput gajah

\begin{abstract}
The research was conducted to determine the morphological characteristics, productivity and quality of Napier grass cultivars Taiwan, King and Mott harvested at 8 and 13 after planting. Effect of cultivar and harvest arranged in a nested design $(3 \times 2)$. The variables were observed consisting of morphological characteristics, dry matter production and forage quality. The results showed that the morphological characteristics, leaf stem ratio, fiber content, crude protein content and in vitro dry matter digestibility of Napier grass Taiwan and King cultivar were not different, but both morphological characteristics, fiber content was higher $(\mathrm{P}<0.05)$ compared to Mott cultivar, whereas leaf stem ratio, crude protein content and in vitro dry matter digestibility Mott cultivar was higher $(\mathrm{P}<0.05)$ compared to Taiwan and King cultivars. In general, an increase in plant height and fiber content at the age of 13 weeks, whereas crude protein content and in vitro dry matter digestibility decreased. It was concluded that the highest dry matter production found in Taiwan and the King cultivars, whereas highest quality found in Mott cultivar. Dry matter production was highest harvested at 13 weeks, whereas the highest quality harvested at 8 weeks after planting for all cultivars tested.
\end{abstract}

Keywords: quality, cultivar, production, Napier grass

\section{INTRODUCTION}

Napier grass [Pennisetum purpureum
(Schum.)] is the main forage in wet tropical regions that have the potential to produce dry matter per unit area compared with other grass 
crops (Hanna et al., 2004). Napier grass has been introduced to all tropical area and grows naturally throughout Southeast Asia where the annual rainfall is about $1000 \mathrm{~mm}$ (Mannetje and Jones, 1992). Napier grass plants can live in soil where other plants are relatively critical not grow well (Sanderson and Paul, 2008). Several cultivars have been developed in Indonesia such cultivar of Africa, Hawaii, Trinidad, Merkeri, King, Taiwan and Mott (Budiman et al., 2011) and varieties of Thailand (Hidayat, 2010). Napier grass is vegetaively propagated and can withstand repeated cutting and rapidly regenerates producing forage which is palatable to cattle at the leafy stage (Maria et al., 2010).

Although cultivars are closely related each other, but there are variations between cultivars such as differences types, namely high and dwarf types. Differences of types causes differences in morphological characteristics. Grasses with higher growth rates tend to have lower nutritive quality as the higher DM production increases the need to form more fibrous cell walls (Wilson and Minson, 1980), on the other hand, grasses with higher growth efficiency tend to have higher nutritive quality (Cid et al., 2008).

Research on the morphological characteristics of Napier grass (Sumarsono et al., 2007) and production and quality cultivars of Bana, Frenc Cameroon and Clone 13 (Nyambati et al., 2007) has been widely applied. The results showed that there were differences in morphological characteristics, production and quality of the cultivar.

The researchers gave different recommendations in determining the exact time of defoliation. The exact timing of defoliation to get optimum production and quality is generally based on the age of the plant and provide recommendations vary. According to Moran (2005) that the grass can be harvested after 25-30 days in the rainy season or 50-60 days in the dry season, while Mwebaze (2002) recommends grass defoliation at the age of 8 to 12 weeks. Zahid et al. (1999) suggested grass defoliation interval with a 10-week high or when the plant reaches $120-150 \mathrm{~cm}$ to obtain results and optimum forage quality. All of the above studies showed that increasing age of the plant, dry matter production also increased, while the quality has declined.

This study aimed to observe the morphological characteristics, quality of Napier grass cultivars Taiwan, King and Mott.

\section{MATERIALS AND METHODS}

\section{Plant Culture}

The materials used were three cultivar of Napier grass planted on 192 pots $(18 \times 35 \mathrm{~cm}$ with diameter $22 \mathrm{~cm}$ ). The pots filled with regosol soils were planted with three different Napier grass cultivars, in which each cultivar required 64 vegetative planting materials. This study consisted of three factors of cultivars and two factors of growth. Cultivar factor of consisted of Taiwan cultivar, King cultivar and Mott cultivar. Meanwhile ages defoliation factor consisted at 8 weeks after planting (8WAP) and 13 weeks after planting (13WAP). Ages of defoliation nested within cultivar factor. Each treatment consisted of four replicates. The pots then were divided according to the cultivar into 3 groups, and each groups were divided into 8 plots, each plot containing of 8 pots. Pots were placed randomly following nested design (Steel and Torrie, 1980) in the pattern of randomization. The distance between each cultivar plots was $60 \mathrm{~cm}$, and between plots ( 8 weeks after planting) and (13 weeks after planting) was $30 \mathrm{~cm}$. Vegetative planting materials (cuttings) napier grass cultivars (Taiwan, King and Mott) were planted in the pots using 3 cutting per pot. Thinning were done after 7 days of growth leaving one the best plant in each pot. Urea fertilizer $(46 \% \mathrm{~N})$, phosphorus $\left(18 \% \mathrm{P}_{2} \mathrm{O}_{5}\right)$ and $\mathrm{KCl}\left(50 \% \mathrm{~K}_{2} \mathrm{O}\right)$ were given at days-3 after thinning at the rate of $100 \mathrm{~kg}$ urea/ha and $50 \mathrm{kgTSP} / \mathrm{ha}$ and $50 \mathrm{KCl} / \mathrm{ha}$ or equivalent to $\left(0.52 \mathrm{~g} \mathrm{~N} /\right.$ pot, $1.33 \mathrm{~g} \mathrm{P}_{2} \mathrm{O}_{5} /$ pot and $0.48 \mathrm{~g}$ $\mathrm{K}_{2} \mathrm{O} /$ pot. Watering and weeding were done if necessary.

\section{Data Collection \\ Morphological Characteristics}

Morphological characteristic measurements included plant height, internode length, stem diameter and leaf stem ratio. Plant height was measured once a week, while the internode, stem diameter and leaf stem ratio is calculated at the time of harvest, i.e. at the age of 8 and 13 weeks after planting.

\section{Dry Matter Production}

Data of production were obtained at 8 and 13 weeks after planting. Plants were harvested at 10 $\mathrm{cm}$ above the soil surface then were weighed to determine the fresh weight. In determining the DM, $200 \mathrm{~g}$ of each sample of Napier grass was 
taken and chopped into short lengths $(2-5 \mathrm{~cm})$. They were then placed in an oven at $55^{\circ} \mathrm{C}$ for 48 hours. The weight after drying is the dry matter (DM). Dried samples then were $1 \mathrm{~mm}$ grounded by Wiley mill. These samples were used to determine the dry matter (AOAC, 2005). Dry matter production was calculated by multiplying the percentage of the total dry matter production of fresh of materials.

\section{Chemical Analysis and in vitro Digestibility}

The dry samples were ground using a hammer mill fitted with a $1 \mathrm{~mm}$ sieve and about $100 \mathrm{~g}$ was stored in separate bottles for analysis. Crude protein was determined according to the method of Association of Official Analytical Chemist (AOAC, 2005). Neutral detergent fiber (NDF), acid detergent fiber (ADF), acid detergent lignin (ADL) by the methods of Goering and Van Soest (1970). Determination of in vitro digestibility was conducted by the methods of Tilley and Terry (1963).

\section{Data Analysis}

The effects of cultivars and harvested were determined by analysis of variance (ANOVA) according to Steel and Torrie (1980). The differences between treatment means were determined using honestly significant difference test (HSD).

\section{RESULTS AND DISCUSSION}

\section{Morphological characteristics}

Morphological characteristics of Napier grass Taiwan, King and Mott cultivars are presented in Table 1. Plant height, stem diameter and internode Taiwan and King cultivars were not different, but both have height, internode and stem diameter were higher $(\mathrm{P}<0.05)$ compared to the Mott cultivar, otherwise the leaf stem ratio of Mott cultivar was higher $(\mathrm{P}<0.05)$ compared to the Taiwan and King cultivars. The difference between the type of cultivar caused the differences establishment and growth of new cells that occurs in intercalary meristem located at the base of internode (Trlica, 1999). Muldoon and Pearson (1979) states that there are differences in the morphological characteristics of Napier grass cultivar. Internode of Mott cultivar varied between 0.2 to $1.5 \mathrm{~cm}$ (Roodrigues et al., 1987). In contrast to report Sollenberger (2008) that the internode of Mott cultivar shorter $(2.54 \mathrm{~cm})$ compared with the high type of Napier grass
(10.16 to $15.25 \mathrm{~cm})$. Length internode difference between type dwarf with the high type is caused by differences in the rate of cell elongation. In this case, Roodrigues et al. (1987) showed that the pattern of internode elongation Mott cultivar because the differentiation of the apical meristem.

The plant height of Taiwan and King cultivars were higher $(\mathrm{P}<0.05)$ harvested at 13 weeks compared to the harvested at 8 weeks, while the Mott cultivar were not increased with increasing maturity. Internode and stem diameter also increased at 13 weeks for all cultivars tested, otherwise the leaf stem ratio decreased with increasing maturity of the plant. According to Vendramini (2010), the decline of the leaf stem ratio caused stem elongation and plant maturity increased.

\section{Dry Matter (DM) Production}

Dry matter production is an important indicator of forage production because the plant dry matter is considered as a manifestation of all the processes and the events that occur in plant growth. The average dry matter production of Napier grass Taiwan, King and Mott cultivars at the different ages are presented in Table 2. Dry matter production of Taiwan and King cultivars were not different, but both production were higher $(\mathrm{P}<0.05)$ compared to the Mott cultivar. The high production of dry matter of the Taiwan and King cultivars compared to the Mott cultivar caused by the growth rate of Taiwan and King cultivars faster so accumulate more dry matter compared to the Mott cultivar. In addition, the plant height of Taiwan and King cultivars were higher than Mott cultivar (Table 2) caused higher dry matter production. According to Obok et al. (2012) that there is a high correlation between plant height and dry matter production. Ha et al. (1996) reported that dry matter production of Taiwan cultivar in Vietnam varies by location and season. In Hanoi City dry matter production to an average of 31.6 tons/ha in the wet season and 21.8 tons/ha in the dry season, while in Ho Chi Minh City 29.2 tons/ha in the wet season and 19.3 tons/ha in the dry season. Dry matter production of Mott cultivar 20.84 tons/ha (Tekletsadik et al., 2004). Dry weight of all cultivars increased with increasing frequency of defoliation the plant. Dry weight of King cultivar 3.980 tons/ha/year, 5.357 tons/ha/year, 7.757 tons/ha/year and 10.248 tons/ha/year, respectively, defoliation frequencies 4, 6, 8 and 10 weeks.

Dry matter production harvested at 13 weeks 
Table 1. The Average Morphological Ccharacteristics of Napier Grass of Taiwan, King and Mott Cultivars at Age of 8 and 13 Weeks after Planting

\begin{tabular}{|c|c|c|c|c|}
\hline \multirow[b]{2}{*}{ Treatment } & \multicolumn{4}{|c|}{ Morphological Characteristics } \\
\hline & $\begin{array}{l}\text { Plant Height } \\
\quad(\mathrm{cm})\end{array}$ & $\begin{array}{l}\text { Internode } \\
(\mathrm{cm})\end{array}$ & $\begin{array}{l}\text { Diameter Stem } \\
(\mathrm{cm})\end{array}$ & $\begin{array}{c}\text { Leaf Stem Ratio } \\
(\%)\end{array}$ \\
\hline \multicolumn{5}{|l|}{ Cultivars } \\
\hline Taiwan & $263.66^{\mathrm{a}}$ & $11.67^{\mathrm{a}}$ & $1.49^{\mathrm{a}}$ & $1.92^{\mathrm{b}}$ \\
\hline King & $243.56^{\mathrm{a}}$ & $10.52^{\mathrm{a}}$ & $1.35^{\mathrm{a}}$ & $2.40^{\mathrm{b}}$ \\
\hline Mott & $115.38^{\mathrm{b}}$ & $2.41^{\mathrm{b}}$ & $1.05^{\mathrm{b}}$ & $9.24^{\mathrm{a}}$ \\
\hline \multicolumn{5}{|l|}{ Harvested } \\
\hline \multicolumn{5}{|l|}{ Taiwan } \\
\hline 8 weeks & $219.19^{\mathrm{b}}$ & $11.02^{\mathrm{a}}$ & $1.47^{\mathrm{a}}$ & $1.56^{\mathrm{a}}$ \\
\hline 12 weeks & $308.13^{\mathrm{a}}$ & $12.32^{\mathrm{a}}$ & $1.50^{\mathrm{a}}$ & $0.73^{\mathrm{b}}$ \\
\hline \multicolumn{5}{|l|}{ King } \\
\hline 8 weeks & $201.13^{\mathrm{b}}$ & $10.30^{\mathrm{a}}$ & $1.33^{\mathrm{a}}$ & $2.47^{\mathrm{a}}$ \\
\hline 12 weeks & $286.00^{\mathrm{a}}$ & $10.74^{\mathrm{a}}$ & $1.36^{\mathrm{a}}$ & $0.95^{\mathrm{b}}$ \\
\hline \multicolumn{5}{|l|}{ Mott } \\
\hline 8 weeks & $104.75^{\mathrm{a}}$ & $1.62^{\mathrm{a}}$ & $1.05^{\mathrm{a}}$ & $13.53^{\mathrm{a}}$ \\
\hline 12 weeks & $126.01^{\mathrm{a}}$ & $3.21^{\mathrm{a}}$ & $1.05^{\mathrm{a}}$ & $4.95^{\mathrm{b}}$ \\
\hline
\end{tabular}

Superscript (a.b) on the column cultivars and harvested indicates significantly different at $(\mathrm{P}<0.05)$

after planting were higher $(\mathrm{P}<0.05)$ compared to that harvested at 8 weeks after planting for all cultivars tested. The high dry matter production harvested at 13 weeks due to the increase of biomass due to the increasing maturity of the plant. According Sitompul and Guritno (1995) that the production of biomass resulting in weight gain.

The average ADL content of Napier grass Taiwan, King and Mott cultivars were harvested at 8 and 13 weeks after planting are presented in Table 2. The high content of ADL in Taiwan and King cultivars due to the high proportion of stem or leaf stem ratio (Table 1) is low, because the stems contain a lignin is higher than the leaves. Conversely, cultivars Mott lower because a higher proportion of leaves than stems. The results Tsuruta et al. (2002) also found differences in cultivars Mott ADL content (5.01\%) and cultivars Taiwan (8.67\%).

\section{Forage Quality}

The average crude protein content of Napier grass Taiwan, King and Mott cultivars were harvested at 8 and 13 weeks after planting are presented in Table 2. Crude protein content of Taiwan and King cultivars were not significantly different, but both contain crude protein was lower $(\mathrm{P}<0.05)$ compared to the Mott cultivar. Crude Protein content of Mott cultivar was higher ( $\mathrm{P}<0.05)$ compared to the Taiwan and King cultivars . Crude protein content of Mott cultivar was higher because it has a high leaf stems ratio (Table 1), because the leaf stem ratio can affect to the quality (Meheffey et al., 2005; Huston and Pinchal, 2008). In general, the leaves contain crude protein higher than the stem (Cheeke, 2005), as the highest quality materials can be found in the more metabolically active tissues such as young leaves (Redfearn, 2008; Huston and Pinchal, 2008).

Crude protein content harvested at 13 weeks after planting were lower $(\mathrm{P}<0.05)$ compared to harvested at 8 weeks after planting for all cultivars tested. This is caused different of stage maturity. In the process of development, the grass plant changes from vegetative to reproductive stage. According to Rayburn (1993), the plant has changed from the vegetative phase to the reproductive phase, quality will be reduced 
Table 2. The Average Production and Quality of Napier grass of Taiwan, King and Mott cultivars at Age 8 and 13 Weeks after planting

\begin{tabular}{|c|c|c|c|c|c|c|}
\hline \multirow{3}{*}{ Treatments } & \multirow{3}{*}{$\begin{array}{c}\text { Dry Matter } \\
\text { Production } \\
\text { (tons/ha) }\end{array}$} & \multicolumn{5}{|c|}{ Quality } \\
\hline & & \multicolumn{4}{|c|}{ Chemical Components (\%) } & \multirow{2}{*}{$\begin{array}{l}\text { IVDM } \\
(\%)\end{array}$} \\
\hline & & $\mathrm{CP}$ & NDF & $\mathrm{ADF}$ & Lignin & \\
\hline \multicolumn{7}{|l|}{ Cultivars } \\
\hline Taiwan & $2.40^{\mathrm{a}}$ & $8.49^{\mathrm{b}}$ & $76.67^{\mathrm{b}}$ & $49.26^{\mathrm{b}}$ & $8.57^{\mathrm{b}}$ & $53.02^{b}$ \\
\hline King & $2.09^{\mathrm{a}}$ & $8.27^{\mathrm{b}}$ & $75.41^{\mathrm{b}}$ & $48.12^{\mathrm{b}}$ & $7.98^{\mathrm{b}}$ & $53.66^{\mathrm{b}}$ \\
\hline Mott & $0.91^{\mathrm{b}}$ & $10.85^{\mathrm{a}}$ & $59.73^{\mathrm{a}}$ & $40.70^{\mathrm{a}}$ & $4.90^{\mathrm{a}}$ & $63.58^{\mathrm{a}}$ \\
\hline \multicolumn{7}{|l|}{ Harvested } \\
\hline \multicolumn{7}{|l|}{ Taiwan } \\
\hline 8 weeks & $1.10^{\mathrm{b}}$ & $10.67^{\mathrm{a}}$ & $72.47^{\mathrm{a}}$ & $46.23^{\mathrm{a}}$ & $7.11^{\mathrm{a}}$ & $58.27^{\mathrm{b}}$ \\
\hline 12 weeks & $3.70^{\mathrm{a}}$ & $6.31^{b}$ & $78.86^{\mathrm{b}}$ & $52.29^{\mathrm{b}}$ & $10.04^{\mathrm{b}}$ & $47.78^{\mathrm{a}}$ \\
\hline \multicolumn{7}{|l|}{ King } \\
\hline 8 weeks & $0.98^{\mathrm{b}}$ & $10.43^{\mathrm{a}}$ & $72.09^{\mathrm{a}}$ & $45.51^{\mathrm{a}}$ & $7.02^{\mathrm{a}}$ & $59.16^{\mathrm{b}}$ \\
\hline 12 weeks & $3.21^{\mathrm{a}}$ & $6.11^{\mathrm{b}}$ & $78.72^{\mathrm{b}}$ & $50.73^{\mathrm{b}}$ & $8.95^{\mathrm{b}}$ & $48.15^{\mathrm{a}}$ \\
\hline \multicolumn{7}{|l|}{ Mott } \\
\hline 8 weeks & $0.06^{\mathrm{b}}$ & $12.94^{\mathrm{a}}$ & $56.74^{\mathrm{a}}$ & $38.23^{\mathrm{a}}$ & $4.04^{\mathrm{a}}$ & $66.63^{b}$ \\
\hline 12 weeks & $1.76^{\mathrm{a}}$ & $8.77^{\mathrm{a}}$ & $62.72^{\mathrm{b}}$ & $43.17^{b}$ & $5.76^{\mathrm{b}}$ & $60.53^{\mathrm{a}}$ \\
\hline
\end{tabular}

Superscript (a.b) on the column cultivars and harvested significantly different at $(\mathrm{P}<0.05)$

due to the increased maturity. In reproductive stage proportion of more stem increases cause increased fiber and crude protein content decreased. According to Wong (1996) that the crude content of Napier grass King and Mott cultivars decreased with increasing defoliation interval.

At defoliation intervals of $3,6,9$ and 12 weeks, crude protein content of Mott cultivar $14.7 \%, 14.4 \%, 15.9 \%, 9.3 \%$ and King cultivar $13.0 \%, 8.5 \%, 8.0 \%$ and $7.5 \%$, respectively. The same was found in the Taiwan cultivar, where the crude protein content decreased $12.25 \%, 11.00 \%$ and $9.65 \%$ at defoliation intervals of 20,30 and 40 days, respectively (Tudsri et al., 2002).

The content of fiber (NDF, ADF and ADL) Napier grass Taiwan and King cultivar were not different, but both contain fiber was higher $(\mathrm{P}<0.05)$ higher compared to fiber Mott cultivar. The NDF content of Taiwan and King cultivars was higher because the proportion of stem both cultivars was higher or lower leaf stem ratio (Table 1.) compared to Mott cultivar. Stem contains NDF higher than leaves (Ball et al., 2001) and most of total NDF is related to stem tissue (Hoffman et al., 2004). According to Henning et al. (2000) that NDF represents all structures or all forage cell wall material. The ADF content of Napier grass Taiwan and King cultivars were not different, but both contains $\mathrm{ADF}$ was $(\mathrm{P}<0.05)$ higher compared to the Mott cultivar. The high content of ADF Taiwan and King cultivars due to differences leaf stem ratio (Table 1). The leaf stem ratio Taiwan and King cultivars relatively lower causes higher ADF content. Some researchers reported that the content of the ADF Mott cultivar in the wet season was $32.9 \%$ and $36.1 \%$ in the dry season (Tekletsadik at al., 2004), King cultivar 35.8\% (Van Man and Wiktorsson, 2003) and 31.1\% in Taiwan cultivar (Grande et al., 2005).

The average ADL content of Napier grass Taiwan, King and Mott cultivars were harvested at 8 and 13 weeks after planting are presented in Table 2. The high content of ADL in Taiwan and King cultivars due to the high proportion of stem 
or leaf stem ratio (Table 1) is low, because the stems contain a lignin is higher than the leaves. Conversely, cultivars Mott lower because a higher proportion of leaves than stems. The results Tsuruta et al. (2002) also found differences in ADL content of cultivars Mott (5.01\%) and cultivars Taiwan $(8.67 \%)$.

Fiber content (NDF, ADF and ADL) harvested at 13 weeks after planting were higher $(\mathrm{P}<0.05)$ than the fiber content harvested at 8 weeks for all cultivars tested. Increased fiber components caused by the increasing proportion of the stem, where the stem fiber is higher than the leaves.

Dry matter in vitro digestibility were not different of Taiwan and King cultivar, but both were lower ( $\mathrm{P}<0.05$ ) compared to Mott cultivar. The high digestibility of dry matter on Mott cultivar compared to Taiwan and King cultivar due to the low content of ADF on Mott cultivar (Table 2) because the proportion of lower stem. The proportion of high stem contains a high ADF. The ADF includes cellulose and lignin are difficult to digest by animals. The results are consistent with those reported Horrocks and Vallentine (1999) that the ADF content were negatively correlated with digestibility of forage. If the ADF increases, digestibility of feed is usually decreased (Schroeder, 1994).

Dry matter in vitro digestibility harvested at 13 weeks after planting were higher $(\mathrm{P}<0.05)$ compared to the dry matter in vitro digestibility harvested at 8 weeks for all cultivars tested. The low dry matter digestibility harvested at 13 weeks due to the increase in the ADF content. Stur and Horne (2000) reported that the dry matter digestibility Napier grass is $60 \%, 55 \%$ and $45 \%$, respectively defoliation frequencies of 3,6 and 9 weeks. On the Taiwan cultivar digestibility was $65.2 \%, 64.5 \%$ and $57.7 \%$ respectively in the frequency of defoliation 4, 5 and 8 weeks (Van Man and Wiktorsson, 2003).

\section{CONCLUSION}

It can be concluded that the rate of developmental morphology and the highest dry matter production on the Taiwan and King cultivars, while the highest quality found in Mott cultivars. Dry matter production was highest harvested at 13 weeks, while the highest quality harvested at 8 weeks after planting for all cultivars tested.

\section{ACKNOWLEDGMENT}

The authors thank to the Directorate General of Higher Education, Ministry of National Education for funding this research through a Doctoral Dissertation Grant Program Letter of Agreement in accordance with the Implementation of Research Dissertations No: 481/SP2H/PP/DP2M/VI/2010, dated June 11, 2010 .

\section{REFERENCES}

AOAC. 2005. Official Methods of Analysis Association (18 ${ }^{\text {th }}$ Ed.), Official Analytical Chemist. Association of Official Analytical Chemist, Washington, DC.

Ball, D.M., M. Collins., G. D. Lecefield., N. P. Martin., D. A. Mertens., K. E. Olson., D. H. Putnam., D. J. Undersander and M. W. Wolf. 2004. Understanding Forege Quality. American Farm Bureau Federation Publication 1-01, Park Ridge,Il.

Budiman, R. D. Soetrisno, S. P. S. Budhi and A. Indrianto. 2011. Total non-structural carbohydrate (TNC) of three cultivars of Napier grass (Pennisetum purpureum) at vegetative and reproductive phase. J. Indonesian Trop. Anim. Agric. 36(2):126 -130 .

Cheeke, P. R. 2005. Applied Animal Nutrition Feeds and Feeding. $3^{\text {rd }}$ Ed. Pearson Prentice Hall. Upper Saddle, New Jersey.

Cid, M. S., Ferri, C. M., Brizuela, M. A. and O. Sala. 2008. Structural heterogeneity and productivity of a tall fescue pasture grazed rotationally by cattle at four stocking densities. Grassland Science. 54: 9-16.

Grande, D., F. Reyes, H. Losada, J. Nahed, N. Romero, G. Valdivieso and F. Perez-Gill. 2005. Response of sheep fed with tropical tree legume foliage and Taiwan grass (Pennisetum purpureum). In: Silvopasturalism and Sustainable Land Management. (M.R. Mosquera-Losada, J.McAdam and A.Ruqueiro-Rodriques, eds). CABI Publishing, Cambridge. P. 134-136.

Goering, H.K. and P.J. Van Soest. 1970. Forage Fiber Analysis. Agriculture Handbook No. 379. Agriculture Research Service. United States Depart of Agriculture. Inc., Englewood Cliffs, New York

Ha, N.N., D. Huynh, D.T.Ty and P.T. Phan. 1996. Evaluation of some forage Crops in 
smallholder of Vietnam. Fifth Proceedings: Forage Regional Working Group of East Asia.

Henning, J.C., G.D. Lacefield, and D. AmaralPhillips.2000. Interpreting Forage Quality Report. Cooperative Extension Service. University. College of Agriculture.

Hidayat, N. 2010. Aplikasi pupuk organik cair terhadap produksi bahan kering, kandungan protein kasar dan serat kasar rumput gajah varietas Thailand. J. Ilmiah Inkoma. 21(3) : 169-177.

Hoffman, P.C., K.M. Lundberg, L.M. Bauman, and R.D. Shaver. 2003. The Effect of Maturity on NDF Digestibility. Focus on Forage Vol 5 No. 15.

Horrocks, R.D. and J. F. Vallentine. 1999. Harvest Forages. Academic Press. San Diego.

Mannetje, L. and R. M. Jones. 1992. Plant Resources of South-East Asia. No. 4. Forages. Pudoc Scientific Publishers, Wageningen.

Maria. M., T. Rego, J. Neuman , M. Neiva, A. C. do Rego, M. D. J. Candido, M.S. de Sousa Carneiro, and R.N.B. Lobo. 2010. Chemical and bromatological characteristics of elephant grass silages containing a mango by-product. Rev. Bras. Zoot. 39(1): 81-87.

Mehaffey, M. H., D. S. Fisher and J. C. Burns. 2005. Photosynthesis and nutritive value in leaves of three warm-season grasses before and after defoliation. Agronomy J. 97: 755 59.

Moore, K. J. and L. E. Moser. 1995. Quantifying developmental morphology of perennial plants. Crop Sci. 35: 37 - 47.

Moore, K. L., L. E. Moser, K. P. Vogel, S. S. Waller, B. E. Johnson and J. F. Pedersen. 1991. Describing and quantifying growth stages of perennial forage species. Agron. J. 83:1073 - 77.

Muldoon, D. K. and C. J. Pearson. 1979. Morphology and physiology of regrowth of the tropical tall grass hybrid Pennisetum. Annual of Botani (G.B.) 43: 719 - 28.

Mwebaze, S. 2002. Pasture improvement technologies based on an on-farm study in Uganda. Regional Land Management Unit (RELMA). Department of Animal Production and Marketing, MAAIF, P.O. Box 513, Entebbe Uganda.

Nyambati, E.M., F.N. Muyekho, C.M. Luwesti and E. Ongonjo. 2007. Production, characterization and nutritional quality of
[Pennisetum purpureum (Schum) cultivars in western Kenya. Proceedings, The $8^{\text {th }}$ African Crop Science Sosiety Conference, El-MiniaEgypt, Oktober 27 - 31, 2007, Page 185 188.

Obok, E.E., M. E. Aken'Ova and G. A. Iwo. 2012. Forage potentials of interspecific hybrids between elephant grass selections and cultivated pearl millet genotypes of Nigerian origin. J. Plant Breeding and Crop Sci. Vol. $4(9): 136-143$.

Parsons, D., D. Cherney and D. J.R. Cherney. 2011. Morphological Staging of Perennial Grasses. Grass Information Sheet Series. Cornell University Cooperative Extention.

Rayburn, E. B. 1993. Plant Growth and Development as the Basis of Forage Management. West Virginia University Extension Service.

Rodrigues, L. R. D.E.A., G. O Mott, J.B. Veiga, and W.R. Ocumpaughh. 1987. Tillering and morphological characteristics of dwarf elephant grass under grazing. Pesquisa Agropecuaria Brasileira (Bra. ) 21(11):120918.

Sanderson, M. A. and R. A. Paul. 2008. Perennial forages as second generation bioenergy crops. Int. J. Molecular Sci., 9 :768-788.

Schroeder, J.W. 1994. Interpreting Forage Analysis. North Dakota State University Agriculture and University Extension. AS1080.

Sitompul, S. M. and B. Guritno. 1995. Analisis Pertumbuhan Tanaman. Gadjah Mada University Press.

Sollenberger, L.E. 2008. Mott elephant grass. University of Florida, IFAS, Florida A. \& M. University Cooperative Extension Program. SS-AGR-58

Steel, R. G. D. and J. H. Torrie. 1980. Principles and Procedures of Statistics. McGraw-Hill Book Co. Inc. New York.

Stur, W. W. and P. M. Horne. 2000. Developing forage technologies with smallholder farmers. Published by ACIAR and CIAT. ACIAR Monograph. No. 88.

Sumarsono, S. Anwar, S. Budianto and D. W. Widjajanto. 2007. Penampilan morfologi dan Produksi bahan kering hijauan rumput gajah dan kolonjono di lahan pantai yang dipupuk dengan pupuk organik dan dua level pupuk urea. J. Indonesian Trop. Anim. Agric. 32(1) : 58-63

Tekletsadik, T., S. Tudsri, S. Juntakool and S. 
Prasanich. 2004. Effect of Dry Season Cutting Management on Subsequent Forage Yield and Quality of Ruzi (Brachiaria ruziziensis) and Dwarf Napier (Pennisetum purpureum L.) in Thailand. Kasetsart J. (Nat. Sci.) $38: 457-67$

Tilley, J. M. A. and R. A. Terry. 1963. A two stage technique for the in vitro digestion of forage crops. J. Brit. Grassl. Soc. 18 : $104-11$.

Trlica, M. J. 1999. Grass growth and response to grazing. Colorado State University. Cooperative Extension. Range. Natural Resource Series. No. 6.108.

Tsuruta, S., R. Akashi, O. Kawamura and H. Namaguchi. 2002. Phylogenic variation of morphological characteristics and their relationship with brix and lignin content in Napier grass (Pennisetum purpureun Schumach ). Grassl. Sci. 47(6):604 - 609.

Tudsri, S., S.T. Jorgenson, P. Riddach and A. Pookpakdi. 2002. Effect of cutting height and dry season closing date on yield and quality of five napier grass cultivars in Thailand. Tropical Grassland. 36:248-52.

Van Man, N. and H. Wiktorsson. 2003. Forage yield, nutritive value, feed intake and digestibility of three grass species as affected by harvest frequency. Trop. Grassl. 37:10110.

Vendramini, V. 2010. Forage Evaluation and Quality in Florida. Proceedings. The $21^{\text {st }}$ Annual Florida Ruminat Nutrition Symposium. Best Western Gateway Grand Hotel Gainesville, Florida, Department of Animal Sciences University of Florida. Institute of Food and Agricultural Sciences Gainesville, Florida, 2-3 February, 2010. p $92-106$.

Wilson, J. R. and D. J. Minson. 1980. Prospects for improving the digestibility and intake of tropical grasses. Tropical Grasslands. 14:253-259.

Wong, C.C. 1996. Productivity and sustainability of some selected tropical fodder grasses for smallholders. Fifth Proceedings: Forage Regional Working Group of East Asia.

Zahid, M.S., M. U. Mufti, M. B. Bhatti, and A. Ghafoor.1999. Nitrogen fertilizer requirement of elephant grass cv. Mott grown in Pothwar area. J. Sci. Tech. and Develop. 18: 25 - 30. 